\title{
Influence of dbcAMP on the inhibitory effect of cumulus cell factor(s)
}

\author{
J Petr *, L Zetová, J Fulka Jr
}

Research Institute of Animal Production, 10400 UhrInĕves, Prague 10, Czechoslovakia

(4th Franco-Czechoslovak Meeting, Prague 1990)

\begin{abstract}
Summary - The factor (s) produced by porcine cumulus cells (cumulus cell factor (s): CCF) was described as quantitatively inhibiting the maturation of oocytes in vitro (Petr et al, 1989).

When 1, 10, 20 or 40 cumulus oocyte complexes (COCs) were cultured in a droplet of medium (vol $10 \mu \mathrm{l}$ ), germinal vesicle breakdown (GVBD) was observed in $85,78,57$ or $19 \%$ of the oocytes, respectively. GVBD was observed in $82,84,80$ or $90 \%$ of cumulus-free oocytes, respectively, when they were cultured at the same numbers per $10-\mu l$ droplet. When $1,10,20$ or 40 cumulus-free 00 cytes were cultured under the same conditions in a medium containing $140 \mathrm{dbcAMP}$ per $\mathrm{ml}, 61,63$,

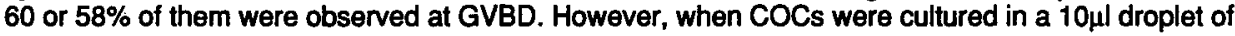
medium with $140 \mu \mathrm{g}$ of dbcAMP per ml, GVBD occurred in $64,42,9$ or $0 \%$ respectively. Based on these results, we can conclude that dbCAMP exerted a further inhibitory effect on GVBD in pig oocytes cultured under the influence of inhibitory factor(s) from cumulus cells. On the other hand, dbcAMP was shown to partly overcome the effect of CCF on GVBD in porcine oocytes. This suggestion was based on the finding that a 6-h pre-culture of COCs in a medium with $1000 \mu \mathrm{g}$ of dbcAMP significantly decreased the subsequent effect of CCF (GVBD: $44 \%$ ) compared with those precultured in a medium with $140 \mu \mathrm{g}$ of dbcAMP/ml (GVBD: $5 \%$ ) or without dbcAMP (GVBD: $15 \%$ ). It is clear that this effect of dbcAMP was due only to transient exposure to the high dbcAMP concentration because 24-h culture of COCs in a 10- $\mu$ l droplet of a medium with $1000 \mu \mathrm{g}$ of dbcAMP/ml resulted in GVBD in only $2 \%$ of the COCs.
\end{abstract}

oocyte maturation / cumulus oophorus inhibitor / CAMP

Résumé - Influence du dbcAMP sur l'effet inhibiteur de facteurs des cellules du cumulus oophorus. Un article préliminaire (Petr et al, 1989) a porté sur le(s) facteur(s) produit(s) par les cellules du cumulus oophorus de porc [facteur(s) des cellules du cumulus - (FFC)] qui inhibe(nt) quantitativement la maturation des ovocytes in vitro.

Après la culture de 1, 10, 20 ou 40 complexes-oocytes-cumuli (COC) dans une goutte (10 $\mu$ l) de milieu, on observe la rupture de la vésicule germinative (RVG) dans $85,75,57$ ou $19 \%$ des ovocytes, respectivement. Lorsque le même nombre d'ovocytes est cultivé sans cumulus dans le même volume de milieu, la RVG est respectivement de $82,84,80$ et $90 \%$. Lorsque des ovocytes sans cumulus sont cultivés dans le milieu contenant $140 \mu \mathrm{g}$ de dbcAMP (dibutyryl AMP cyclique) par ml, 61, 63,60 ou $58 \%$ subissent la RVG. Enfin, quand les COC sont cultivés dans le milieu contenant 140 $\mu g$ de dbcAMP par ml, la RVG se produit respectivement dans $64,42,9$ et $0 \%$. Nous concluons de ces résultats que les effets du dbcAMP peuvent s'additionner à ceux du FCC pour inhiber la RVG de l'ovocyte de porc.

D'autre part, un prétraitement par le dbcAMP serait capable d'inhiber partiellement l'effet de FCC sur la RVG d'ovocytes porcins. En effet, une préculture de 6 h de COC, dans le milieu contenant 1000

\footnotetext{
* Correspondence and reprints
} 
$\mu \mathrm{g} / \mathrm{ml}$ de dbcAMP, a diminué significativement l'effet subséquent de FCC (44\% de RVG); la préculture dans un milieu contenant $40 \mu g$ de dbcAMP/m/ ou sans db cAMP a donné respectivement 5 et $15 \%$ de RVG. II est clair que l'effet de dbcAMP est dû au traitement transitoire à forte concentration : $24 \mathrm{~h}$ de culture de COC dans $10 \mu /$ de milieu contenant $1000 \mu \mathrm{g}$ de db cAMP/m/ a donné seulement $2 \%$ de RVG.

\section{maturation ovocytaire / Inhibition / cumulus oophorus / AMPC}

\section{INTRODUCTION}

In vivo fully grown, non-atretic follicles are arrested before the first meiotic division until the preovulatory surge of gonadotropins initiates meiosis resumption (Thibault, 1977). Follicle-enclosed oocytes cultured in vitro remain immature until they are exposed to luteinizing hormone (LH) (Lieberman et al, 1976). However, when oocytes are liberated from antral follicles and cultured, they resume meiotic maturation spontaneously, independently of hormonal stimulation (Pincus and Enzman, 1935). These observations indicate that follicular cells are responsible for meiotic arrest (Sato and Koide, 1987; Thibault et al, 1987). The mechanism involved in the maintenance of meiotic arrest has not yet been determined but studies in laboratory animals indicate that there may be more than one means of control.

To date, several potential inhibitors have been described: cyclic adenosine 3', $5^{\prime}$ monophosphate (cAMP), oocyte maturation inhibitor (OMI), granulosa cell factor (GCF) and, lately, purine nucleotides (Sato and Koide, 1987).

Dekel et al (1988) have suggested that in the rat, cAMP has a dual role in the regulation of oocyte maturation. Lower levels of this nucleotide act to maintain meiotic arrest, while elevated levels of cAMP mediate $\mathrm{LH}$ action to induce meiosis resumption. A similar dissociation between the inhibitory and the stimulatory action of CAMP on maturation of oocytes was observed in rabbits (Hosoi et al, 1989). In the mouse, follicular components such as follicular fluid could synergize with cAMP to prevent meiotic resumption (Downs and Eppig, 1984).

As described in our previous study (Petr et al, 1989), porcine cumulus cells produce at least one factor quantitatively inhibiting germinal vesicle breakdown (GVBD) in pig oocytes. This inhibitory factor acts indirectly on oocytes through the mediation of cumulus cells. The inhibition of GVBD is reversible but the addition of LH or heparin only partially overcomes the inhibitory action.

The present study was undertaken to clarify the influence of CAMP analog, dibutyryl cyclic adenosine 3' 5' monophosphate (dbcAMP), on the inhibitory effect of factor (s) from porcine cumulus cells.

\section{MATERIAL AND METHODS}

Pig oocytes were aspirated from follicles of about 3-5 mm in diameter. Oocytes with compact cumuli were washed 3 times in medium and then cultured in 10- $\mu$ l droplets of medium under paraffin oil at $38^{\circ} \mathrm{C}$ in air with $5 \% \mathrm{CO}_{2}$ for $24 \mathrm{~h}$. Preliminary studies showed that after this interval GVBD occurred under our culture conditions. The composition of the medium was the same as described by Fulka et al (1986). Denuded oocytes were prepared by repeated pipetting of cumulus-enclosed oocytes through a narrow pipette and cultured in the same way.

dbcAMP (Serva, Heidelberg, Germany) was used when the oocytes were cultured in $10-\mu$ l droplets of medium containing 140 or $1000 \mu \mathrm{g}$ of dbcAMP per ml. 
The influence of dbcAMP on the inhibitory effect of factor(s) from cumulus cells was investigated using the culture of different numbers $(1$, $10,20,40$ ) of denuded or cumulus-enclosed oocytes in a 10- $\mu$ d droplet of medium with or without dbcAMP $(140 \mu \mathrm{g} / \mathrm{ml})$ for $24 \mathrm{~h}$.

The influence of transient exposure of COCs to dbcAMP on the subsequent inhibitory effect of factor(s) from cumulus cells was studied as follows: four groups of 10 COCs were precultured for $6 \mathrm{~h}$ in a 10- $\mu \mathrm{l}$ droplet of medium with different concentrations of dbcAMP $(0,140$ or $1000 \mu \mathrm{g} / \mathrm{ml})$. Following this interval, the COCs (ie 40 COCs) were carefully washed and cultured together in one 10- $\mu$ l droplet of medium without dbcAMP.

At the end of culture the oocytes were mounted on slides, fixed in acetic alcohol $(1: 3 \mathrm{v} / \mathrm{v})$ for at least $24 \mathrm{~h}$, stained with $1 \%$ orcein and examined under a phase contrast microscope. Results were compared with the $\chi^{2}$ analysis.

\section{RESULTS}

As described previously (Petr et al, 1989), a high concentration of cumulus cells exerts a quantitative inhibitory effect upon GVBD of porcine oocytes cultured in vitro.

When $1,10,20$ or 40 COCs were cultured for $24 \mathrm{~h}$ in a 10- $\mu$ l droplet of culture medium, GVBD was observed in 85,78 , 57 and $19 \%$, respectively (fig 1 ). The percentage of GVBD in denuded oocytes cultured under the same conditions was not influenced by the increasing number of oocytes per 10- $\mu$ l droplet and was about $80 \%$. When $1,10,20$ or 40 denuded oocytes were cultured in a 10- $\mu$ ldroplet of medium with $140 \mu \mathrm{g}$ of dbcAMP per $\mathrm{ml}$, GVBD was observed in $61,63,60$ or $58 \%$ of oocytes, respectively. However, when the same numbers of COCs were cultured in a medium with dbcAMP, the GVBD percentage was $64,42,9$ and $0 \%$, respectively.

Based on these data we can conclude that dbcAMP can exert a further inhibitory effect on GVBD in oocytes cultured under the influence of inhibitory factor(s) produced by cumulus cell.

To test the effect of temporal exposure of pig oocytes to dbcAMP on the effects of inhibitory factor(s) from cumulus cells (fig 2), 4 groups of 10 COCs were pre-cultured in 10- $\mu$ l droplets for $6 \mathrm{~h}$. After this interval the COCs were removed, carefully washed and cultured together in one 10- $\mu$ l droplet (ie 40 oocytes per droplet) of medium with or without dbcAMP for $18 \mathrm{~h}$. The maturation of oocytes pre-cultured in dbcAMP. free medium or in medium with $140 \mu \mathrm{g}$ of dbcAMP per $\mathrm{ml}$ was significantly inhibited (GVBD 15 or $5 \%$, respectively). However, 6-h exposure of 10 oocytes per droplet to a

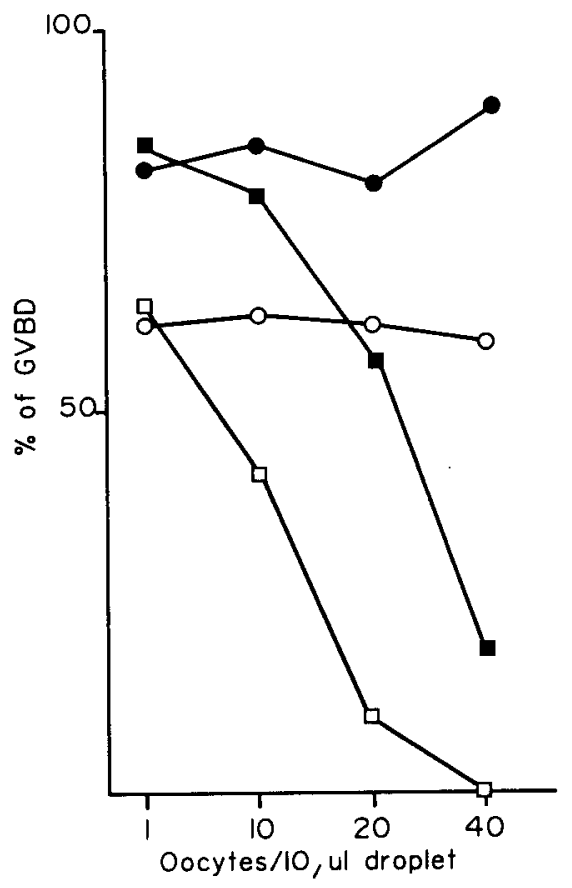

Fig 1. The influence of dbcAMP on the effect of inhibitory factor from porcine cumulus cells. Different numbers of COCs were cultured in medium without $(-\square-)$ or with $140 \mu \mathrm{g}$ of dbcAMP per ml (- - - . Denuded oocytes were cultured at the same numbers in the medium without $(-\mathrm{O}-$ ) or with dbcAMP (-O-). 


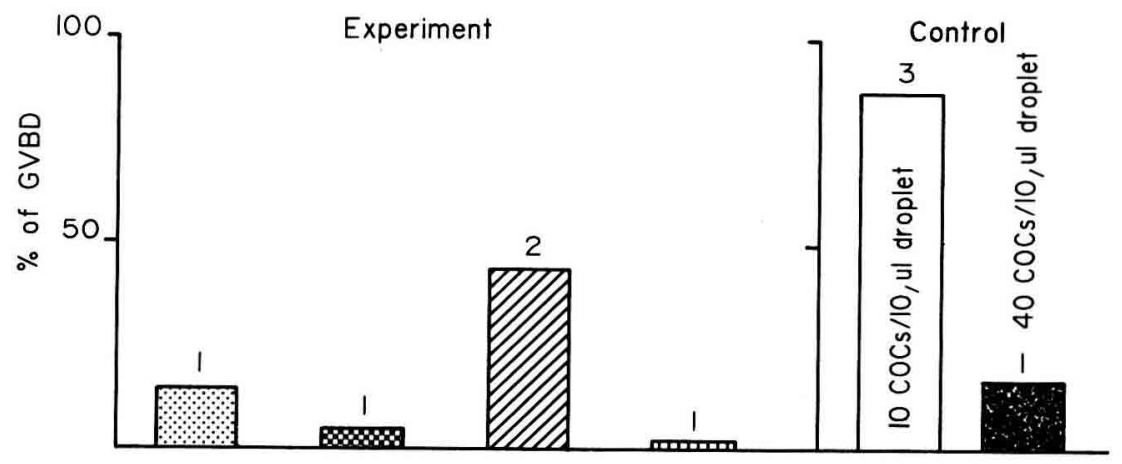

Fig 2. The influence of transient exposure of COCs to dbcAMP upon the inhibitory effect of factor from porcine cumulus cells. Before exposition to the inhibitory influence of factor from cumulus cells, COCs were pre-cultured for $6 \mathrm{~h}$ in the medium without dbcAMP (horizontally hatched column), or in the medium with $140 \mu \mathrm{g}$ of dbcAMP per $\mathrm{ml}$ (cross hatched column), or in the medium with $1000 \mu \mathrm{g}$ of dbcAMP per $\mathrm{ml}$ (transversely hatched column). The percentage of GVBD in COCs cultured in the medium with $1000 \mu \mathrm{g}$ of dbcAMP per $\mathrm{ml}$ for $24 \mathrm{~h}$ is shown by the vertically hatched column. Control oocytes were cultured for $24 \mathrm{~h}$ in dbcAMP-free medium in numbers of 10 (blank column) or 40 (black column) per $10 \mu \mathrm{l}$ droplet. Statistically significant differences $(P<0.01)$ are indicated by different numbers above columns.

medium with $1000 \mu \mathrm{g}$ of dbcAMP per $\mathrm{ml}$ could partially overcome the subsequent effects of high COC: medium vol ratio (GVBD 44\%). On the other hand, 24-h culture of 40 oocytes in a 10- $\mu$ l droplet of medium with $1000 \mu \mathrm{g}$ of dbcAMP per $\mathrm{ml}$ did not exert a similar effect (GVBD 2.5\%).

When 10 or 40 COCs were cultured for control in the dbcAMP-free medium, GVBD was observed in $88 \%$ or $17 \%$ after $24 \mathrm{~h}$.

\section{DISCUSSION}

Cyclic AMP has been proposed as a physiological intrafollicular inhibitor of oocyte maturation. The inhibitory effect of cAMP derivates on isolated oocytes and be overcome by luteinizing hormone (LH) (Dekel and Beers, 1978, 1980).
The present study demonstrates that the inhibition of GVBD in pig oocytes, which is due to the effect of factor(s) from cumulus, can be further increased by the addition of dbcAMP. A similar effect on pig oocyte maturation was observed after the culture of oocytes in medium with dbcAMP and testosterone (Rice and McGaughey, 1981). The authors concluded that this inhibitory action was mediated through cumulus cells. Cyclic AMP can stimulate aromatase activity in cultured granulosa cells. Oestrogen may be implicated in the observed inhibition of pig oocyte maturation (Richter and McGaughey, 1979; Racowsky and McGaughey, 1982). In the light of these data we cannot exclude the possibility that steroids are at least partly involved in the action of inhibitory factor(s) produced by porcine cumulus cells.

Our results suggest that CAMP may play a significant role in the intrafollicular arrest 
of oocyte meiosis in pigs, as was demonstrated in other mammalian species (Cho et al, 1974; Dekel and Beers, 1978; Dekel et al, 1984, 1988; Hosoi et al, 1989), and they are consistent with other reports on pig oocyte maturation (Racowsky, 1983, 1985).

On the other hand, it is well established that CAMP plays a role as a mediator of $\mathrm{LH}$ induction of oocyte maturation (Dekel and Sherizly, 1983; Dekel et al, 1988).

It was suggested by Dekel and Sherizly (1983) that LH-induced maturation is a cAMP-mediated response during which cAMP levels are elevated. We have tried to mimic this situation by the transient exposure of COCs under the influence of inhibitory factor from cumulus cells to dbcAMP at a concentration of $1000 \mu \mathrm{g}$ per $\mathrm{ml}$. Six-h culture of only 10 oocytes per droplet was shown to be insufficient to influence the resumption of meiosis; $18 \mathrm{~h}$ appears to be sufficient either to affect the arrest of meiosis or to induce the GVBD. For this reason, 6-h pre-culture of COCs was performed before 18-h exposure of oocytes to the influence of inhibitory factor(s) from cumulus cells. This transient exposure to dbcAMP significantly increased the percentage of GVBD in COCs subsequently exposed to the influence of a high amount of cumulus cells, which is usually able to inhibit GVBD. Permanent exposure to this concentration of dbcAMP or transient exposure to lower dbcAMP levels (0 or $40 \mu \mathrm{g} / \mathrm{ml}$ ) had no similar effect.

These observations lend support to the suggestion that in pigs, as in rats (Dekel et al, 1988) and rabbits (Hosoi et al, 1989), the increased dbcAMP concentration can affect the cumulus cells and interrupt communication in the COCs. This is consistent with our previous observation that denuded pig oocytes are not affected by the influence of inhibitory factor(s) from cumulus cells. During the permanent culture of
COCs in medium with $1000 \mu \mathrm{g}$ of dbcAMP per $\mathrm{ml}$, the COCs could be maintained at the GV stage by dbcAMP alone because denuded pig oocytes did not undergo GVBD after culture in the medium with this concentration of dbcAMP (data not shown).

Since LH was described to partially overcome the inhibitory effect of cumulus cells (Petr et al, 1989) and LH is known to induce oocyte maturation through its effect on the somatic follicular periovarian cells (Dekel and Beers, 1980), we can suggest that in pre-ovulatory follicles of the pig, in response to $\mathrm{LH}$, follicular cAMP levels are elevated; these increased CAMP levels interrupt communication in the COCs, and the flow of inhibitors (including CAMP and inhibitory factor(s) produced by cumulus cells) to the oocyte decline. Following this, meiosis can resume.

Based on these observations we can conclude, at least in relation with cumulus cell inhibitory factor(s), that cAMP plays a dual role in the maturation of pig oocyte. It is involved in the maintenance of meiotic arrest and in the LH-mediated processes which cause the GVBD.

\section{REFERENCES}

Cho WK, Stern S, Biggers JD (1974) Inhibitory effect of dibutyryl CAMP on mouse oocyte maturation in vitro. J Exp Zool 187, 383-386

Dekel N, Aberdam E, Sherizly I (1984) The spontaneous maturation in vitro of rat cumulus-enclosed oocyte is inhibited by forskolin. Biol Reprod 31, 244-250

Dekel N, Beers WH (1978) Rat oocyte maturation in vitro: relief of cyclic AMP inhibition by gonadotropins. Proc Natl Acad Sci USA 75, 4364-4373

Dekel N, Beers WH (1980) Development of rat oocyte in vitro: inhibition and induction of maturation in the presence or absence of the cumulus oophorus. Dev Biol 75, 247-252 
Dekel N, Galiani D, Sherizly I (1988) Dissociation between the inhibitory and the stimulatory action of CAMP on maturation of rat 00 cytes. Mol Cell Endocrinol 56, 115-121

Dekel N, Sherizly I (1983) Induction of maturation in rat follicle-enclosed oocytes by forskolin. FEBS Lett 151, 153-155

Downs SM, Eppig JJ (1984) Cyclic adenosine monophosphate and ovarian follicular fluid act synergistically to inhibit mouse oocyte maturation. Endocrinology 114, 418-427

Fulka J Jr, Motlík J, Fulka J, Jilek F (1986) Effect of cycloheximide on nuclear maturation of pig and mouse oocytes. J Reprod Fertil $77,281-285$

Hosoi $Y$, Yoshimura $Y$, Atlas SJ, Adachi T, Wallach EE (1989) Effects of dibutyryl cyclic AMP on oocyte maturation and ovulation in the perfused rabbit ovary. J Reprod Fertil 85 , 405-411

Lieberman ME, Tsafriri A, Bauminger S, Collins WP, Ahren K, Lindner HR (1976) Oocyte meiosis in cultured rat follicles during inhibition of steroidogenesis. Acta Endocrinol Copenh 83, 151-157

Petr J, Zetová, L Fulka Jr J, Jilek (1989) Quantitative inhibitory influence of porcine cumulus cells upon the maturation of pig and cattle oocytes in vitro. Reprod Nutr Dev 29, 541 550

Pincus G, Enzmann EV (1935) The comparative behaviour of mammalian eggs in vivo and $i n$ vito. I. The activation of ovarian eggs. $J$ Exp Med 47, 665

Racowsky C (1983) Adrenergic modulation of cyclic adenosine monophosphate (CAMP) dependent meiotic arrest. Biol Reprod 28, 774-787

Racowsky C (1985) Effect of forskolin on maintenance of meiotic arrest and stimulation of cumulus expansion, progesterone and cyclic AMP production by pig oocyte-cumulus complexes. J Reprod Fertil 74, 9-21

Racowsky C, McGaughey RW (1982) In the absence of protein, estradiol suppresses meiosis of porcine oocytes in vitra $J$ Exp Zool 224, 103-110

Rice C, McGaughey RW (1981) Effect of testosterone and dibutyryl cAMP on the spontaneous maturation of pig oocytes. $J$ Reprod Fertil 62, 245-256

Richter JD, McGaughey RW (1979) Specificity of inhibition by steroids of porcine oocyte maturation in vitro. J Exp Zool 209, 81-90

Sato E, Koide SS (1987) Biochemical transmitters regulating the arrest and resumption of meiosis in oocytes. Int Rev Cytol 106, 1-33

Thibault $C$ (1977) Are follicular maturation and oocyte maturation independent processes? $J$ Reprod Fertil 51, 1-15

Thibault C, Szöllösi D, Gérard M (1987) Mammalian oocyte maturation. Reprod Nutr Dev 27, 865-896 